\title{
STUDIES ON THE BIOCHEMICAL DEFECT OF PERNICIOUS ANEMIA. I. IN VITRO OBSERVATIONS ON OXYGEN CONSUMPTION, HEME SYNTHESIS AND DEOXYRIBONUCLEIC ACID SYNTHESIS BY PERNICIOUS ANEMIA BONE MARROW ${ }^{1,2}$ \\ By E. DONNALL THOMAS AND HARRY L. LOCHTE, JR. ${ }^{3}$ \\ [From the Mary Imogene Bassett Hospital (Affiliated with Columbia University), Cooperstown, $N . Y$.]
}

(Submitted for publication August 8, 1957; accepted October 14, 1957)

In microbiological systems, folic acid and vitamin $B_{12}$ appear to be important in the synthesis of purines and pyrimidines, in the synthesis of methyl groups, and possibly in the synthesis of deoxyribose (1-3). Studies at the clinical level, summarized by Mueller and Will (4), indicate that similar biochemical processes may be involved in patients with pernicious anemia (P. A.). Because such studies on patients are difficult to carry out and interpret, precise methods of in vitro assessment of the biochemical activity of P. A. marrow cells are needed.

Direct studies on P. A. marrow have been confined, for the most part, to observations of morphologic changes and cell counts in tissue culture (5-12). In attempting to avoid the difficulties inherent in evaluating these changes in tissue culture and in an effort to secure more direct biochemical information, P. A. marrow has been studied in our laboratory by the following techniques: 1) oxygen consumption, 2) heme synthesis as measured by the rate of incorporation of $\mathrm{C}^{14}$ glycine into heme, and 3) deoxyribonucleic acid (DNA) synthesis by measurement of the rate of incorporation of $\mathrm{C}^{14}$-formate into thymine.

With these techniques, which permit measurements of biochemical activity over short periods of time and with small amounts of bone marrow, we have attempted to answer the following questions: 1) Does vitamin $B_{12}$ have a direct effect on P. A. marrow cells? 2) Why has the liquid culture-vaccine vial technique failed to demonstrate an

\footnotetext{
1 Supported by a research grant (C-2643) from the United States Public Health Service.

2 Presented in part before the National Meeting of the American Federation for Clinical Research at Atlantic City, May 5, 1957.

3 Public Health Service Research Fellow of the National Heart Institute.
}

effect of vitamin $B_{12}$ ? 3) Is there an inhibitory factor in P. A. serum? 4) What is the effect of folic acid on P. A. cells?

\section{METHODS}

Bone marrow was obtained by aspiration biopsy from patients with classical pernicious anemia in relapse. The marrow was dispersed by passage through wire screens, and aliquots were pipetted into incubation vessels. The suspending media were varied according to the conditions being studied. In making the various dilutions, care was taken to keep the concentration of serum and of radioactive substrate constant in all aliquots of any given experiment. The methods for measuring oxygen consumption, heme synthesis and DNA synthesis have been described $(13,14)$. In measuring heme synthesis, the concentration of glycine-2- $\mathrm{C}^{14}$ was $1.4 \mu \mathrm{M}$ per ml. of medium, and the specific activity was $0.2 \mathrm{mc}$. per mM. In measuring DNA synthesis, the concentration of $\mathrm{C}^{14}$ formate was $0.5 \mu \mathrm{M}$ per ml. of medium, and the specific activity was $2.0 \mathrm{mc}$. per $\mathrm{mM}$. At the end of the period of incubation, aliquots of carrier rabbit bone marrow were added to the incubation vessels to facilitate the subsequent isolation of thymine. In any one experiment, therefore, the absolute value of the specific activity of the isolated thymine is a function of the amount of carrier added. Crystalline vitamin $B_{12}$, folic acid and folinic acid were obtained through the courtesy of Lederle laboratories.

\section{RESULTS}

Table I illustrates a comparison, with regard to heme synthesis and oxygen consumption, of P. A. bone marrow incubated in P. A. serum, normal serum, and P. A. serum plus $0.1 \gamma$ of vitamin $B_{12}$ per $\mathrm{ml}$. As was indicated previously (13), the comparison of different serum samples is difficult because of a wide range of variability among different normal serum samples from hematologically normal donors. This difficulty is apparent in attempting to compare P. A. serum to 
TABLE I

Heme synthesis and oxygen consumption by pernicious anemia bone marrow incubated in pernicious anemia serum, normal serum, and pernicious anemia serum plus $0.1 \gamma$ of vitamin $B_{12}$ per ml.*

\begin{tabular}{|c|c|c|c|c|}
\hline \multirow[t]{2}{*}{ EXPT. } & \multicolumn{2}{|c|}{$\begin{array}{l}\text { COMPARISON OF PERNICIOUS } \\
\text { ANEMMA SERUM TO MORMAL } \\
\text { SERUM AS } 100 \%\end{array}$} & \multicolumn{2}{|c|}{$\begin{array}{l}\text { COMPARISON OF PERIMCIOUS ANEMIA } \\
\text { SERUM PLUS BR TO PERNICIOUS } \\
\text { ANEMLA SERUM ALONE AS } 100 \%\end{array}$} \\
\hline & Mane SMTTHESAS & arrezn consunpinon & HEWE SWTTHESAS & 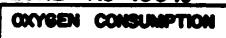 \\
\hline 1 & 127 & 120 & & \\
\hline 2 & 112 & 99 & & \\
\hline 3 & 66 & 93 & & \\
\hline 4 & 126 & 113 & & \\
\hline 5 & 195 & 102 & & \\
\hline 6 & 125 & 108 & 89 & 92 \\
\hline 7 & 100 & 112 & 109 & 103 \\
\hline 8 & 95 & 91 & 80 & 100 \\
\hline 9 & 51 & 94 & 110 & 102 \\
\hline 10 & 108 & 109 & $\mathbf{I I}$ & 99 \\
\hline 11 & 112 & & 102 & \\
\hline 12 & 141 & 100 & 104 & 102 \\
\hline MEAN & 113 & 104 & 101 & 100 \\
\hline S.D. & 36 & 9 & 12 & 4 \\
\hline
\end{tabular}

* Each experiment represents a different P. A. marrow. The time of incubation for heme synthesis was 10 hours with oxygen consumption being measured during the first 3 hours.

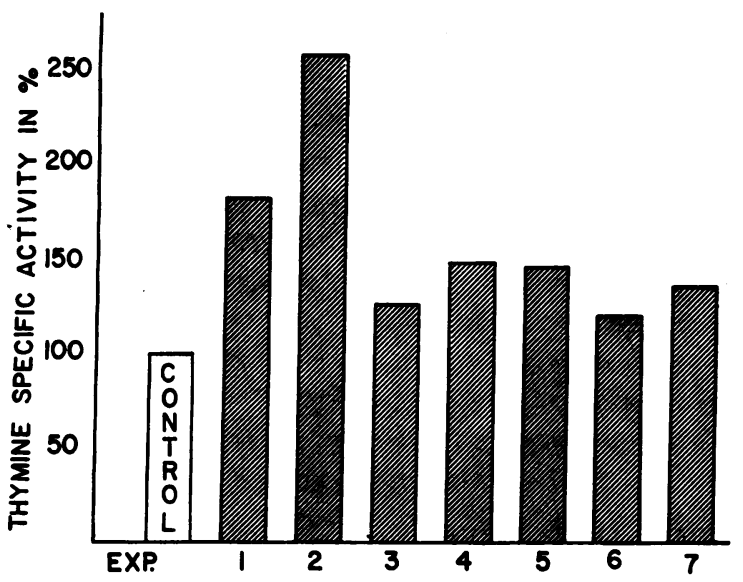

Fig. 1. The Effect of Vitamin $B_{12}$ on Deoxyribonucleic Acid Synthesis by Pernicious Anemia Marrow in Pernicious Anemia Serum

In Experiments 1 and 2, the period of incubation was 10 hours; in Experiments 3 through 7, 5 hours. In Experiments 1 through 5 the concentration of vitamin $B_{12}$ was $0.1 \gamma$ per $\mathrm{ml}$; in Experiments 6 and 7, $0.01 \gamma$ per $\mathrm{ml}$. In each experiment the control was an aliquot of the P. A. marrow incubated in $P$. A. serum without added vitamin $B_{12}$. normal serum, as indicated by the large standard deviation. In comparing the effect of $P$. A. serum with and without added vitamin $B_{12}$, we used aliquots of the same serum in each of the experiments, with the result that the standard deviation is much smaller. It is apparent that, within the limits of the technique, there is no effect of either

TABLE II

The effect of various concentrations of vitamin $B_{12}$. on deoxyribonucleic acid synthesis by pernicious anemia marrow in pernicious anemia serum incubated for five hours

$\mathrm{B}_{12}$

$\mathrm{CPM} / \mu \mathrm{M}$

$\mathrm{r} / \mathrm{ml}$.

of Thymine

$\begin{array}{ll} & 2830 \\ 0.1 & 3970 \\ 0.01 & 4030 \\ 0.001 & 3920\end{array}$




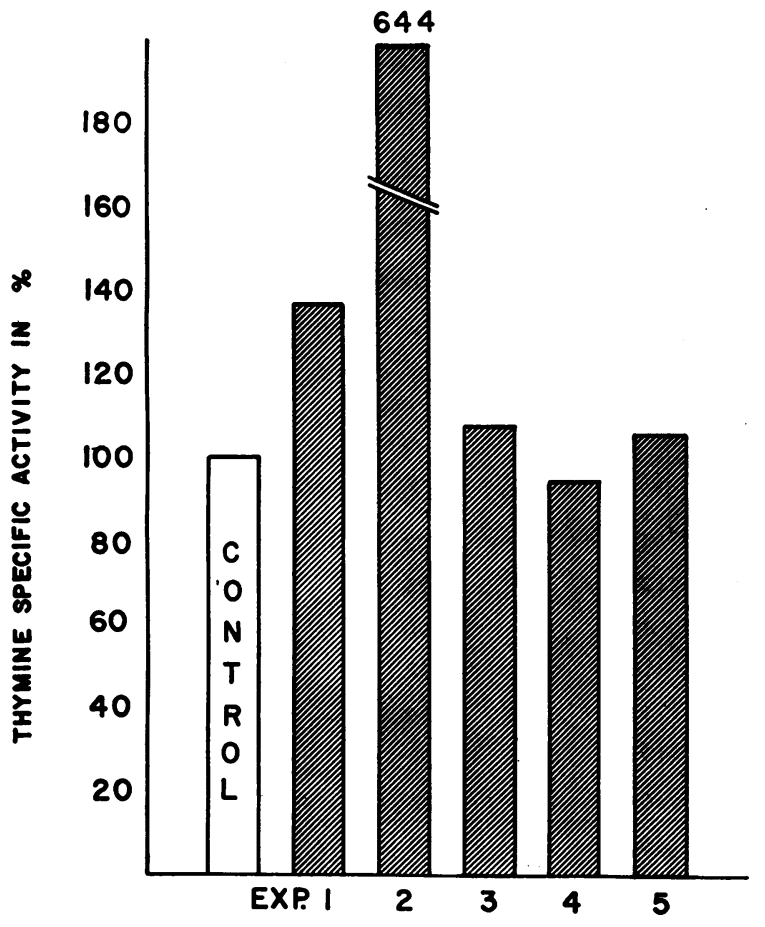

Fig. 2. The Effect of Folic Acid on Deoxyribonucleic Acid Synthesis by Pernicious Anemia Marrow in Pernicious Anemia Serum

In Experiments 1 and 2 the period of incubation was 10 hours; in Experiments 3 through 5, 5 hours. The concentration of folic acid was $0.2 \gamma$ per $\mathrm{ml}$. In each experiment the control was an aliquot of the P. A. marrow incubated in P. A. serum without added folic acid.

normal serum or vitamin $B_{12}$ on these two processes.

Figure 1 illustrates the effect of vitamin $B_{12}$ on DNA synthesis by P. A. marrow cells in P. A. serum. The results illustrated in this figure show that vitamin $\mathrm{B}_{12}$ does have a direct and consistent effect at the cellular level. The amount of vitamin $B_{12}$ used in these experiments is considerably above the normal range of 100 to $900 \mu \mu \mathrm{g}$. per $\mathrm{ml}$. (15). The data in Table II show that $0.001 \mu \mathrm{g}$. per $\mathrm{ml}$. also produces an optimal effect. In three experiments the addition of vitamin $B_{12}$ to normal serum produced no significant increase in the rate of DNA synthesis by P. A. marrow.

Figure 2 illustrates the effect of folic acid on DNA synthesis by P. A. marrow cells in P. A. serum. In three experiments there was no effect, in one there was a moderate stimulation, and in one there was marked stimulation. In one other experiment, the addition of folic acid to P. A. mar- row in normal serum also produced a marked increase in DNA synthesis. It appears, therefore, that P. A. marrow cells differ considerably in their response to folic acid. In three experiments, no difference between the effect of folic acid and of folinic acid was observed.

Table III illustrates two experiments that have been done to test the effect of vitamin $B_{12}$ and folic acid singly and in combination. In Experiment $\mathrm{A}$ the marrow was stimulated markedly by folic acid, whereas in Experiment B the folic acid had a barely detectable effect. The effect of the combination of vitamin $B_{12}$ with folic acid was roughly the sum of the individual effects alone. One interpretation of these limited data is that the two substances are not related in their mode of action.

The experiments illustrated in Figures 3A, 3B and $3 \mathrm{C}$ were designed to determine whether or not there is an inhibitor of DNA synthesis in P. A. serum. Figure $3 \mathrm{~A}$ compares the effect of dilution of P. A. serum and normal serum on DNA synthesis by normal marrow, and Figure $3 \mathrm{~B}$ illustrates a similar experiment using $\mathrm{P}$. A. marrow. DNA synthesis by P. A. marrow and normal marrow in various mixtures of $P$. A. serum and normal serum is illustrated in Figure 3C. It is apparent that none of these experiments shows any evidence of an inhibitor of DNA synthesis in P. A. serum.

Studies of DNA synthesis over a 48 hour period are illustrated in Figure 4. Using the vac-

$$
\text { TABLE III }
$$

The effect of vitamin $B_{12}(0.1 \gamma$ per $\mathrm{ml}$. $)$, folic acid $(0.2 \gamma$ per ml.), and both vitamins on deoxyribonucleic acid synthesis by pernicous anemia marrow in pernicious anemia serum incubated for 10 hours

EXPT. SUPPLEMENT

A

NONE

CPM/MM THYMINE

$\mathrm{B}_{\mathbf{R}}$ 265

FOLIC ACID

$B_{12} \&$ FOLIC ACID

1,705

2,410

B

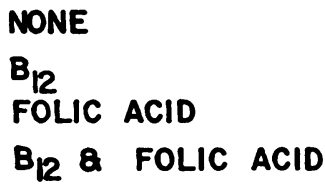

8,900

II, 300

9,500

12, 690 


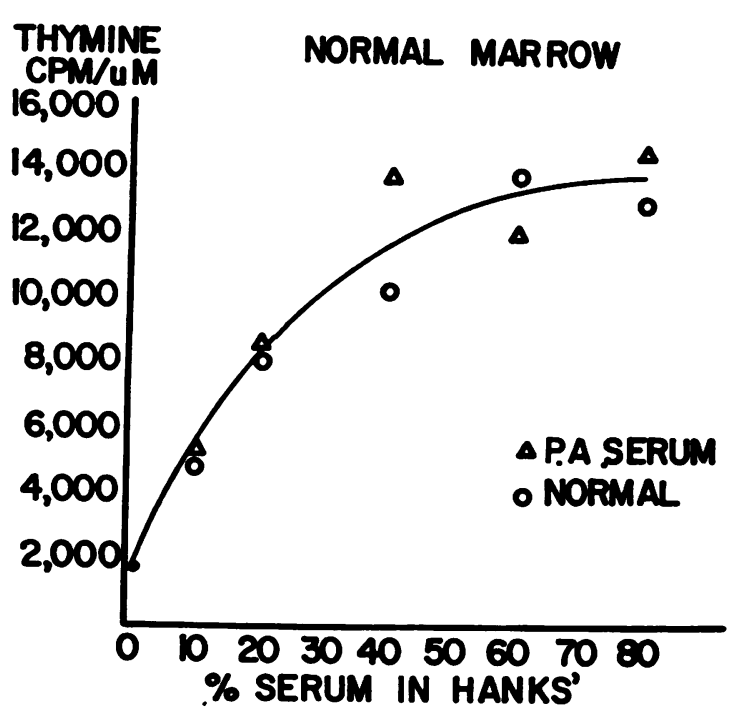

Fig. 3A. The Effect of Dilution of Pernicious Anemia Serum and Normal Serum on DeoxyribonucCleic Acid Synthesis by Normal Marrow

Incubation time was five hours.

cine vial method of Osgood and Brownlee (5), as modified by Lajtha (8), we incubated aliquots of normal marrow in 25 per cent normal serum in Gey's solution. After the various times of incubation, $\mathrm{C}^{14}$-sodium formate was added, and incubation was carried on for an additional four hours. It is apparent from Figure 4 that the ability of marrow cells to synthesize DNA is markedly reduced after 24 hours and has virtually ceased at 48 hours.

\section{DISCUSSION}

These short term experiments with $\mathrm{P}$. A. marrow show a definite effect of vitamin $B_{12}$ on DNA synthesis. No effect was demonstrated on either oxygen consumption or heme synthesis. It is possible that longer experiments would show some effect on heme synthesis, as suggested by the experiments of Walsh, Thomas, Chow, Fluharty, and Finch (16). In the first few hours, vitamin $\mathrm{B}_{12}$ may permit proliferation of cells and then later, as these cells mature, heme synthesis may begin to increase.

Results given here are of particular interest in that they show a definite action of vitamin $B_{12}$ on P. A. marrow cells. Using the liquid suspension culture technique, Lajtha (7) and Thompson (10) observed that folic acid, but not vitamin $\mathrm{B}_{12}$, had a maturing effect on megaloblasts. These observa-

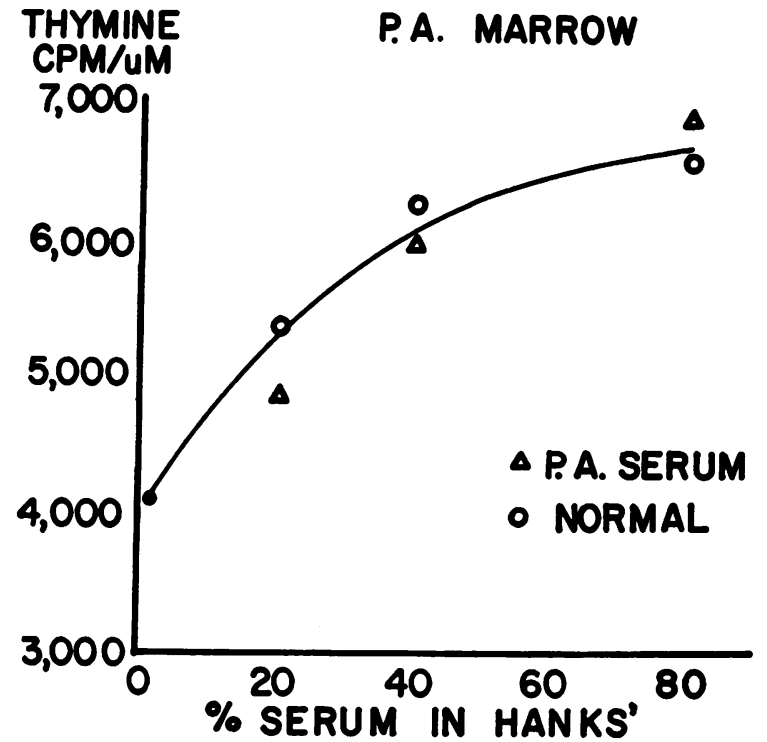

Fig. 3B. The Effect of Dilution of Pernicious Anemia Serum and Normal Serum on Deoxyribonucleic Acid Synthesis by Pernicious Anemia Marrow

Incubation time was five hours.

tions led to the speculation that vitamin $B_{12}$ might combine with an intrinsic factor or be altered in some way to form a hematopoietic factor in serum (10). However, the experimental data reported here demonstrate that vitamin $B_{12}$ in $\mathrm{P}$. A. serum has a direct effect on $P$. A. marrow cells, indicating that an intrinsic factor is not essential to

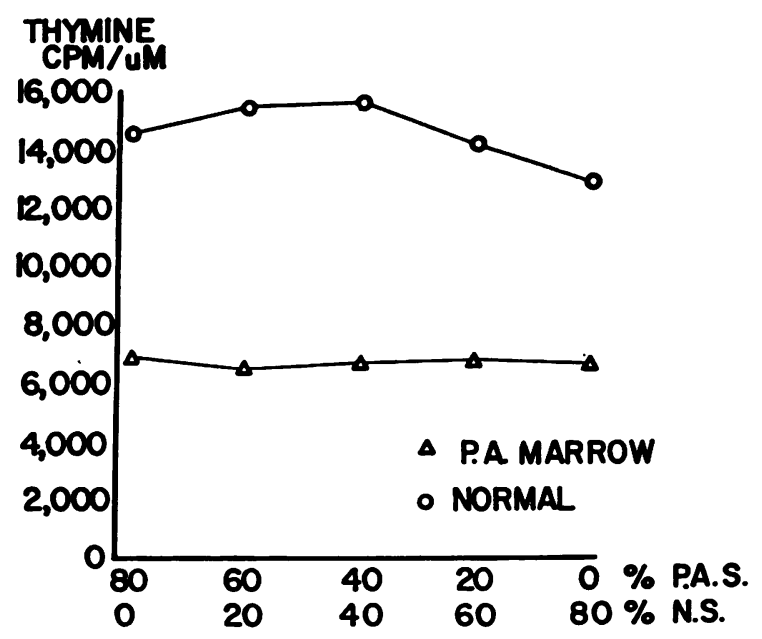

Fig. 3C. The Effect of Various Mixtures of Normal Serum (N. S.) and Pernicious Anemia Serum (P. A. S.) on Deoxyribonucleic Acid Synthesis by Pernicious Anemia Marrow and Normal Marrow Incubation time was five hours. 


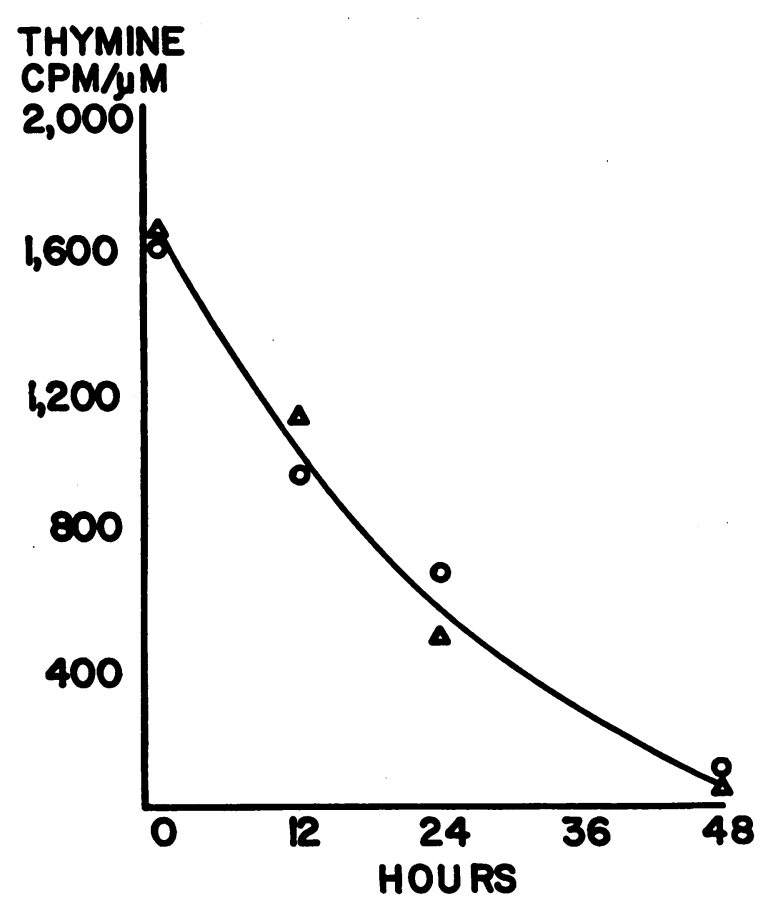

Fig. 4. The Effect of the Time of Preincubation on Deoxyribonucleic Acid Synthesis by Normal Bone Marrow in Vaccine Vial Culture

After the period of culture shown, $\mathrm{C}^{\mathbf{1 4}}$-formate was added to the vial. Incubation was then carried on for an additional four hours. In the experiment shown, the triangles represent a nucleated cell concentration of 3,338 per cu. $\mathrm{mm}$. and the open circles represent a concentration of 1,730 per cu. $\mathrm{mm}$.

the action of vitamin $B_{12}$. The P. A. serum present during incubation has the ability to bind some of the vitamin added in vitro (15). Whether this action is important in the utilization of the vitamin is not known. Experiments have not been conducted in the absence of serum because of the poor preservation and lowered metabolism of the cells in the culture media without serum.

Investigators using the liquid culture-vaccine vial technique have failed to demonstrate a cellular effect of vitamin $B_{12}$. The work of Swan, Reisner, and Silverman (12) indicated that this failure may be due to the limitations of the technique. They. studied the effect of vitamin $B_{12}$ and folinic acid on pernicious anemia marrow in both suspension and solid cultures. Vitamin $B_{12}$ appeared to stimulate cell growth in cultures grown on clots and to convert megaloblastic hematopoiesis to normoblastic in cultures grown on glass. In suspension cultures, on the other hand, folinic acid caused an increase in the number of cells, but vitamin $B_{12}$ did not. Our studies show that after the first few hours of liquid culture, the rate of DNA synthesis falls off very rapidly, indicating a rapid loss of proliferative ability (Figure 4). Lajtha observed a rapid loss of proliferative power of marrow cells in suspension cultures in vitro (8). Swan, Reisner, and Silverman have also commented on the progressive decrease in the number of "mitotable" cells in suspension cultures (12). Since vitamin $B_{12}$ appears to act primarily on DNA synthesis and associated cell proliferation, the rapid loss of these processes in suspension culture makes the interpretation of 48 and 72 hour cultures an unreliable method of studying the action of vitamin $\mathrm{B}_{\mathbf{1 2}}$.

Lajtha (7), Thompson (9), and Bussi, Eridani, Pozza, Fava, and DeMicheli (11) presented data indicating that $\mathrm{P}$. A. serum possesses the property of inhibiting morphological maturation of both P. A. marrow cells and normal marrow cells. Our technique, however, indicates that P. A. serum does not contain an inhibitor of DNA synthesis. The assessment of maturation by morphologic means is dependent primarily on nuclear changes which may not necessarily be associated with the formation of new DNA. Our results do not permit the exclusion of an inhibitor of morphologic maturation in P. A. serum. However, the above-mentioned limitations of the vaccine vial culture technique cast doubt on the existence of a true inhibitor.

One surprising result has been the marked variation in the response of the marrow to added folic acid. In those P. A. marrow cells responding to folic acid, the magnitude of the effect has been much greater than that of vitamin $B_{12}$. Nieweg, Faber, de Vries, and Kroese (17) measured the folic acid activity of the whole blood in 16 patients with pernicious anemia. Normal values were found in about half the cases, with the remainder being low. In our experiments, the marrows responding to folic acid may have come from patients who were deficient in folic acid as well as vitamin $B_{12}$. Blood folic acid levels were not measured.

The technique presented here makes it possible to carry out metabolic studies on marrow cells of man. Experiments along these lines, with various radioactive precursors and with various supple- 
mented media, may eventually shed light on the mode of action of vitamin $B_{12}$ and folic acid. It is hoped that some of these studies can be carried out, although the decreasing number of patients with untreated pernicious anemia constitutes a major problem to those working in this field.

\section{SUM MARY}

Pernicious anemia (P. A.) marrow has been studied in vitro by measuring the rates of oxygen consumption, heme synthesis and deoxyribonucleic acid (DNA) synthesis. From these studies the following conclusions have been drawn:

1. Vitamin $B_{12}$ affects DNA synthesis but not oxygen consumption or heme synthesis.

2. Vitamin $B_{12}$ has a direct effect on DNA synthesis by P. A. marrow cells.

3. Folic acid affects DNA synthesis in different P. A. marrows to a highly variable degree.

4. The liquid suspension-vaccine vial technique - is not a suitable method for studies of DNA synthesis by marrow.

5. P. A. serum does not contain an inhibitor of DNA synthesis.

\section{ACKNOWLEDGMENTS}

The authors are indebted to the following physicians for their generous cooperation in making available suitable case material: William B. Castle, Robert B. Chodos, Franklin G. Ebaugh, Frank H. Gardner, Gerald F. Parkhurst, Simon Propp, and George D. Vlahides.

\section{REFERENCES}

1. Ford, J. E., and Hutner, S. H. Role of vitamin $B_{12}$ in the metabolism of microorganisms in Vitamins and Hormones. New York, Academic Press Inc. 1955, vol. 13, pp. 101-136.

2. Pfiffner, J. J., and Bird, O. D. Water-soluble vitamins. I. Vitamin $B_{12}$, folic acid, choline, and paraaminobenzoic acid. Ann. Rev. Biochem. 1956, 25, 397.

3. Downing, M., and Schweigert, B. S. Role of vitamin $\mathrm{B}_{12}$ in nucleic acid metabolism. IV. Metabolism of $\mathrm{C}^{14}$-labeled thymidine by Lactobacillus Leichmannii. J. biol. Chem. 1956, 220, 521.
4. Mueller, J. F., and Will, J. J. Interrelationship of folic acid, vitamin $B_{12}$ and ascorbic acid in patients with megaloblastic anemia. Amer. J. clin. Nutr. $1955,3,30$.

5. Osgood, E. E., and Brownlee, I. E. Culture of human marrow. Details of a simple method. J. Amer. med. Ass. 1937, 108, 1793.

6. Astaldi, G., Baldini, M., and Frugoni, C., Jr. Transformazione normoblastica del midolio osseo dell'anemia perniciosa ottenuta in vitro per azione diretta dell'estratto epatico. Haematologica 1948, $31,265$.

7. Lajtha, L. G. An inhibitory factor in pernicious anaemia serum. Clin. Sci. 1950, 9, 287.

8. Lajtha, L. G. Culture of human bone marrow in vitro; reversibility between normoblastic and megaloblastic series of cells. J. clin. Path. 1952, 5, 67.

9. Thompson, R. B. Addisonian pernicious anaemia. Confirmatory evidence of a factor inhibiting erythropoiesis. Clin. Sci. 1950, 9, 281.

10. Thompson, R. B. Observations on the effects of vitamin $B_{12}$, liver extracts, folic acid and thymine on the maturation of megaloblasts in culture. Blood 1952, 7, 522.

11. Bussi, L., Eridani, S., Pozza, G., Fava, P. L., and DeMicheli, E. Studi sulla megaloblastogenesi "in vitro" di midolli anemico-perniciosi e normali. Nota I. Biol. lat. (Milano) 1953, 6, 17.

12. Swan, H. T., Reisner, E. H., Jr., and Silverman, M. The effect of various metabolites on the growth of marrow cells in vitro. Blood 1955, 10, 735.

13. Thomas, E. D. In vitro studies of erythropoiesis. I. The effect of normal serum on heme synthesis and oxygen consumption by bone marrow. Blood $1955,10,600$.

14. Thomas, E. D., and Lochte, H. L., Jr. Deoxyribonucleic acid synthesis by bone marrow cells in vitro. Blood 1957, 12, 1086.

15. Lear, A. A., Harris, J. W., Castle, W. B., and Fleming, E. M. The serum vitamin $B_{12}$ concentration in pernicious anemia. J. Lab. clin. Med. 1954, 44, 715.

16. Walsh, R. J., Thomas, E. D., Chow, S. K., Fluharty, R. G., and Finch, C. A. Iron metabolism. Heme synthesis in vitro by immature erythrocytes. Science 1949, 110, 396.

17. Nieweg, H. O., Faber, J. G., de Vries, J. A., and Kroese, W. F. S. The relationship of vitamin $B_{12}$ and folic acid in megaloblastic anemias. J. lab. clin. Med. 1954, 44, 118. 